
HARVARD STUDIES

IN COMPARATIVE LITERATURE

VOLDMES PREVIOUSI $T$ IBSOED

I

THRee PHILOSOPhical POETS LUCBETIUS, DANTE, AND GOETHE BT GEORGE BANTAYANA

II

ChIVALRY IN ENGLISH LITERATURE CHADCER, MALORY, BPENBER, AND BHAKESPEAARE BY WILUIAM HENRY SCHOFTBLD

III

THE COMEDIES OF HOLBERG DY OBCAR JAMES CAMPDELI, JR.

IV

MEDIAEVAL SPANISH ALLEGORY BY CHANDLER RATHEON POBT $\mathbf{v}$

MYTHICAL BARDS

AND

THE LIFE OF WILLIAM WALLACE BY WILLIAM HENRY SCHOFIBLD 


\section{HARVARD STUDIES \\ IN COMPARATIVE LITERATURE \\ FOUNDED BY THE GENERAL EDITOR \\ WILLIAM HENRY SCHOFIELD \\ PROFESSOR OF COMPARATTVE LITERATURE \\ IN HARVARD UNIVERSITY \\ VI \\ ANGEVIN BRITAIN AND SCANDINAVIA}





\title{
HARVARD STUDIES IN COMPARATIVE LITERATURE VOLUME VI
}

\section{ANGEVIN BRITAIN AND SCANDINAVIA}

\author{
BY \\ HENRY GODDARD LEACH \\ SECRETARY OF THE AMERICAN-SCANDINAVIAN \\ FOUNDATION
}

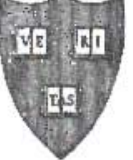

CAMBRIDGE

HARVARD UNIVERSITY PRESS

LONDON: HUMPHREY MILFORD

OXFORD UNIVERSITY PAESS

1921 
COPYRIGHT, 1921

HARVARD UNIVEREITY PRESS 
TO

THE MEMORY OF

WILLIAM HENRY SCHOFIELD

MY TEACHER AND FRIEND

WHOSE INSPIRATION, PRECEPT, AND COUNSEL

DURING FIFTEEN YEARS

HAVE MADE THIS WORK POSSIBLE 
